\title{
Philosophy of Being - The Struggling Self on the Example of Fr. Augustinus a S. Paschali
}

\author{
Sigrid Steinschaden \\ Projects: Mongolia, China \\ sigrid.steinschaden@gmail.com
}

\begin{abstract}
In this paper the topic of personal settlement in another culture - in this case the Chinese one - than the one one has grown in and probable (psychological) difficulties are shown on the example of Fr. Augustinus a S. Paschali. The whole struggle as described by Augustinus is compared to the establishing process of the order itself and any philosophical thoughts of which preferences the soul needs to have when coming to the point of glory vs. joy, being joy a higher reached level of personal approach in dealing with oneself and others. The main point of struggle is the melancholy Augustinus is suffering from, or even just has overcome him due to the experiences made in China, and any remedies and necessities defined in order to reduce or even distinguish the emotional stress his melancholy is causing. The high importance of aware acting is underlined as well as the fact that already in the growing of the order psychological issues were part of the thinking of cultural intercourse within the order and within the whole missionary environment. The struggle itself is furthermore reflected in its personal and institutional corporate intercourse, something of great importance still nowadays in global professional settings.
\end{abstract}

Index Terms - Augustinus a S. Paschali (O.F.M.), Psychological Phenomena of Intercultural Dealing, Personal and institutional corporate intercourse, Resilience \& Perseverance, 17th century

\section{Introduction}

The idea of the topic came to my mind whilst reading the letters of Augustinus a S. Paschali after having had several moments of astonishment concerning his personal struggles fought. It seemed to me that at least several of the struggles related to the topic of loneliness were accompanied by an interpreted other that was either a concrete thinking of the time, especially supported within Franciscan missionaries, or an expectation set by the missionary himself due to the own desire of going into the mission in China by having to accept any situation encountered, independent of own emotional needs [1]. The imagination of a frame that was more than the definitions of the rules as requirements of the individual ready for working and living abroad came up. The interesting aspect I met was the one that the spiritual frame as well as its content defined by Francis of Assisi were quite different from the situation Augustinus thought of being his personal limitation instead of an already thought of psychological issue in doing mission. Therefore Augustinus tended towards defending his own emotional needs, and especially their official expression within some addressees of his letters.

I had to think of how Francis had found his way to

\footnotetext{
${ }^{1}$ NbReg, XVI., 10-12.
}

mission and the (official) legends provided on the various states of psychological and spiritual growing until becoming the initiator of a new organisation he was responsible of. Furthermore I thought of the various prayers and suggestions that are attributed to the Saint and that give a clear idea of the qualitative and responsible reasoning of the person of the missionary within an administrative and therefore more or less hierarchical structure in the context of an intense study of the bible and the human being himself.

\section{The Finding of Franciscan Spirituality as Basis towards Missionary Reflection}

Legend tells that Francis of Assisi made his way in the foundation of the order by three main experiences he had to go through in his life, starting from being the son of a successful merchant from Umbria up to being the founder of a from the very beginning internationally thought of acting spiritual organisation. Even though it is evident - and this is underlined by the selection of the main frescoes in the Upper Church of St. Francis in Assisi whose execution is attributed to Giotto and his school, and that represent as well the history as the spiritual idea of the life of the Saint- that there had been some affinity to following evangelical life already before.

The first of the three experiences can be considered as a reflective turning point that combined the force of leaving homeland by defending Christianity in order to gain knighthood [2] with the intuition of using the peaceful weapons of word and example by spreading the idea of spirituality. The legendary background of this first kind of initialisation can be described as following under the premises given by Thomas of Celano and Bonaventura da Bagnoregio in their biographical works [3] of the Saint.

The implicated development of the personal evolution of Francis in this matter varies within the two versions presented by Thomas of Celano, whereas the version of Bonaventura is containing nothing more than an amendment in one very specific detail to the second legendary version of Thomas. In the first version of Thomas the idea and aim of armed knighthood is much more present than the idea of spiritual knighthood in its social representation. The reason for this can be seen in the fact that this topic was set immediately after the

\footnotetext{
${ }^{2}$ Pope Innocence III had given order in his function as guardian of the young king Frederic Roger from Sicily (known later as king Frederic II) to Walter from Brienne to head a campaign towards Apulia in order to regulate the caotic situation in Southern Italy.

${ }^{3}$ I Cel 5; II Cel 6; LM I,3.
} 
quite obsessive idea of Francis of becoming knight, whereas there is a change in the psychological setting due to the emotional linkage to Francis as follower of St. Martin by giving his coat to a poor man. This setting itself is neither given in the first vita of Thomas nor in Bonaventura, but only with Thomas in the second vita as hinted at before. Furthermore it needs to be pointed out that the whole construction of the change itself is put into the subconsciousness of dream - this is part of all biographical intentions -, what marks this step out of the following two proofs of the spiritual settlement of Francis as shown later on.

There is a remark on the personality of Francis that needs to be considered when discussing the very soon intermingling with other cultures. It is the force of glory [4] that seems to dominate at least in this very special moment over everything else that might be considered driving force in the way of involving oneself and the order into active players of religion and any politics related to it. Of course at that very moment it was not something that was promised for sure but that was evoked by the emotion of desire and fascination of something else being vivid part of the world in a Christian environment than the glory obtained by knighthood. Nevertheless there is some remarkable concept introduced exactly with the original idea of glory that is already substituted in the later biographic versions [5], and can be found again in the writings of Francis [6] as part of his spiritual expression. It can be defined by rich / lord vs. poor, human vs. God, and spirit. Proof about the difference in thinking and its consequences of glory plus the later on introduced ideas give the solutions of dealing with the respective psychological starting point as well as with its way into a life devoted to God. The glory itself is only related to the profane world based in his paternal home of origin as the end of the story is an individual whose mind wants to do something, in this case go on towards Apulia, whereas the sentiment is one of inner force in order to fulfil his plans, and therefore missing joy.

There might be some relation nevertheless given again to the spiritual sources left by Francis especially within the definition of true and full joy [7] where he makes an interesting distinction of specifics of Franciscan life that do not give complete joy and the feeling of complete joy related to patience without spontaneous exaggeration about this motion [8]. One counterpart mentioned is exactly a missionary one: the conversion of those who originally had another belief, as well as the brothers who had left for abroad and been initiators of those conversions [9]. This might be one of the joys of the respective brothers but not of the individual that is Francis, even though he himself has exactly this development in his own biography when his patience is tested precisely in this first experience by looking for his way of glory, or maybe

\footnotetext{
${ }^{4} \mathrm{I}$ Cel 5.

${ }^{5}$ II Cel 6; LM I,3.

${ }^{6}$ comp. ex. BrGlII, 48 / 49; BrKust II, 2 / 3 /4; ErklVat I, 5 / 6 / 7; ErklVat

VII, 1 / 2; MahnKlara / 6.

7 VollFreud

${ }^{8}$ VollFreud 15.

${ }^{9}$ VollFreud 6.
}

value of life before finding his way into religious mission. He has not yet recognized the fulfilment of joy that is very much related to the inspiration given by God in leading ones own conscious and self-defined way of life but has found a kind of confusion that just let him turn back in order to define his inner self in concordance with joy.

This thought is once again expressed in the admonitions as what to seek for in life by preferring insight to comparison with others [10]. In the legends that give hint to a more spiritual approach already God is included as providing a possible solution by leaving the house of the father in order to gain ones palace all the weapons of knighthood are part of as a kind of an intermediate phase until the individual way as follower, creator and inter-mediator within the variety of world is found.

The second experience is the vocation in San Damiano [11] and even there the two vitae as described by Thomas are quite different. In the first one [12] there is an intrinsic development suggested by the appearance of the destroyed church that contains two main symbolic characters that can be found once again in the spiritual writings [13] and can be defined as reciprocal action caused by man that does harm to subjects and objects. Later on we will see that this concept is part of the missionary dealing in China, often related to the phenomenon of the demon as part of the individual in search of ones self and the way in ones life. It is something that is considered not to be supernatural. The main notion is the one of light that needs to be provided before reconstruction or construction work either on the object or the subject, or even on both can begin. There seems to be a simplicity underlying in this concept, wherefore the blindness of the priest in charge of San Damiano needs to be introduced as person under all circumstances as he is part of a church full of exterior wealth and some lack in interior relation to faith in the sense of spirituality as harmony in institutional and global related sense. This lack of faith goes along with a missing faith in oneselves doing, wherefore the priest does not do anything in order to change the situation of the church he is in charge of what means that he does not change his habit towards responsibility of what had been trusted to him as well as conservator of something old as well as creator of something that needs continuation and adaptations at the same time. It is the breakout of a system that seems to be unchangeably stuck and can easily be set into motion again by lightening the weak spots on the surface and enforcing the strength in its inside. It is again much more part of the individuality as a way to independence of thinking related to a set system as it is the obedience of desolation in some sense. In the second vita the concept of intrinsic motivation is replaced by a kind of medium that supports the process of what can be considered enlightenment in or of ones life. As the inspiring words of the cross lead to the same consequence of the simple need of

\footnotetext{
${ }^{10}$ MahnKlara 5 / 6.

${ }^{11}$ I Cel 8; II Cel 9; LM II,1.

${ }^{12}$ I Cel 8.

${ }^{13}$ BrGl I, 8; BrGl II, 66 / 67.
} 
providing light first - with this aspect of giving light Francis always is attributed himself as medium and possible intermediator for others, supposed they accept his doings and suggestions - an interrelation with the view on mission with the help of an authorised individual discussing spiritual, and therefore psychological as well as philosophical questions is given along with the indicated possibility of martyrdom, that is a highly reputed final in the sense of having thought before leaving for the mission on cruel death as consequence of persecution caused by the confrontation with something that might appear, or even be unfamiliar to somebody else. This might cause aggression, a psychological emotion thought of later on by Francis when discussing direct contact with others by enforcing the empathetic part of interaction as a result of watching the given interest of the other in the content of Christian belief as well as the fact that if not such an interest is given nothing should be done that could cause any quarrels except of just confirming the own identity of being Christian [14], both nonetheless being able to incite martyrdom in the one or the other moment [15]. In this context it needs to be mentioned that in the second vita a direct relation with the stigmatisation Francis about 18 years later should experience is set as Thomas knows to report that Francis seemed to be like the one on the cross [16].

The vita as described by Bonaventura is a combination of both before mentioned vitae [17].

The third experience is the recognition of the way to follow in some specific details. It is on one hand considered of having been emotionally expressed with a visible outburst of enthusiasm, something discussed earlier on in the question of joy as being in a relation with patience. It is interesting to see that exactly the emotional outburst is part of the legend of Bonaventura [18] that is dated later than in Thomas'. Thomas [19] shows a reflective young man who waits until the end of the holy mess in order to get the passage - that is one of the envoy of missionaries [20] - he has been fascinated of being explained and interpreted by the priest. Afterwards he started to change himself in his clothing, following the example of the apostles. Again the emotion of joy is introduced, this time with a mind-set that is a combination of purposeful behaviour and reflective patience, later having put into definition of the true clergyman as somebody able of transferring the own joy and fascination given by God to others [21]. The first friar the example is given on is Bernhard of Quintavalle [22].

\footnotetext{
${ }^{14}$ Fragm I, 36 / 37 / 38.

${ }^{15}$ Fragm I, 39 / 40.

${ }^{16}$ II Cel 11.

${ }^{17}$ LM II, 1.

${ }^{18}$ LM III, 1

${ }^{19}$ I Cel 22.

${ }^{20}$ Mt 10,1-15; Mk 6,7-12; LK 9,1-12.

${ }^{21}$ ErklVat XX, 1-3.

${ }^{22}$ I Cel 24.
}

\section{The Thinking of Psychology within the Spirituality of St. Francis as Necessary Frame of Emotional Settings on the example of Augustinus a S. Paschali}

There are two main expressions used by Augustinus that, even though I did not count the quantitative use of them, seemed to be qualitative part of the psychological setting caused mainly by the situation he found himself in during his mission in China. It is the loneliness he found himself in due to the situation in Shandong where huger monastic communities were lacking, distances between villages long, and Augustinus forced to be a kind of single player for and of the Franciscan order. The other expression found quite often was the feeling of an urgent need and must have of perseverance due to exactly the caused loneliness he could not overcome even though he had been aware of possible solutions. Nothing more was the human exchange than an individual professional network lacking any intense friendship that he could not find within people of foreign, respectively Chinese background or friars of other orders and nationality who were often located quite far away. The other main relation put on perseverance was caused by a political issue and its effects on his professional duty as administrator responsible for people, objects and spiritual and legal rights in concordance with the expectations set by his superiors who were located especially due to their high positions already reached, in the centres being in the centre meant having a good administrative and therefore a certain quantity of human resource available and in immediate reach - of missionary 'thinking' such as Rome or the Philippines.

Augustinus is and had located himself consciously in an intellectual and emotional setting that was thought of global acting from the very beginning even though, as it is with organisational development, it was organised originally from a very small nucleus concerning site, that had been in that case Assisi, and people, in that case a small group of idealists who shared the same idea as the founder of the order in their view on the world, on philosophies of human life and aware and open development by introducing cultures that seemed to be worth of being consciously adapted into the own setting.

It is somehow again a similar situation Augustinus found himself in Shandong province where he was expected to organise a group of people in the sense Francis had started his spiritual life with by being an attracting example people liked to follow and discuss its background of ideas of life with, and be open to growth without forcing anyone to join.

Francis, even though internationally thinking was mainly located in his own home country, respectively even home town, that means, he was dealing in the culture he had grown in, whereas any concept he had to think about was reciprocal to experiences made in other towns, villages and countries in comparison to the culture familiar with.

Augustinus instead had already a history and development of the order to task, and was surrounded by and compared with successful missionaries, either probably even of the past of his own order. In that case he would have been compared to missionaries such as John of Montecorvino and 
Andreas of Perugia, maybe even with some envoys who had been very successfully dealing with the foreign cultures by introducing cultural approaches they had learned and later on shared in their reports and itineraries, such as John of Plano Carpini and Wilhelm of Rubruck did for the Mongolian culture, Odoric of Pordenone, John of Marignolli, Peregrinus of Castello and the author of the 'Libro de conoscimiento' for the Chinese one. Immediate predecessors and co-players such as John Baptist Lucarelli of Pisauro, Augustinus of Tordesilla, Ignatius of Loyola, Franciscus a Iesu de Escalona, Antonius a S. Maria Caballero, John of Casanova and Bonaventura de Ibañez wrote a couple of various texts of different sort that even centuries later had been seen as a certain value of spreading experiences made in Asia, especially in China with its direct referrals to political and economic exchange, either of peaceful or bellicose motive.

It is only partially known how Augustinus looked at the other missionaries. He describes and discusses mainly contemporaries according to his own duties and dependencies of their doings and decisions, and involves himself as person mainly when he feels a kind of failure and missing expectations of sorting things out and solving any problems on hand. Due to the dependencies of the administrative overhead centres he points out stressful situations as ships that could not reach its destinations on time due to natural phenomenona as monsoons or floodings or wars that forced ships to take other routes, or did not depart at all or with great delay, or papers and actual decisions and publications of the order missing, that leads to the feeling of not being kept up to date especially when unexpected situations are met.

Together with the emotional feeling of individual loneliness because of lacking co-friars in the daily exchange at the very beginnings of his work in China another pressure of loneliness can be made out in the desperate request for money in order to administrate the whole mission he is in charge of according to local needs and economic requests caused by different costs and calculations based on climate, distances and infrastructure of transportation and trading articles needed for individual and professional use.

Augustinus was quite young - he was about 27 years when he entered the mission to China via Manila, where he was able to adapt himself in an already established environment. When leaving for China on January 10 in the year 1677 from Manila via Macao he was just about 33 years and experienced the first troubles when his licence for working in Guangzhou was rejected. With the age of about 40 all the troubles of loneliness started when he had been chosen to start his mission in Shandong province.

Augustinus from then on defines himself as a melancholic character [23]. He uses the word 'señoreado' by melancolia in order to express that it is something he cannot be active sovereign of, but instead it is something he is unexpectedly, probably in reaction to certain situations that provoked those feelings, overwhelmed by. His remedy found to deal with,

\footnotetext{
${ }^{23}$ Augustinus, IX, 1, ( 1936, p. 437f.).
}

what he exactly defines as 'enfermdad' [illness], is reading, something that cannot for long time be an alterantive for him to missing society of co-nationals. In this context he introduces the relationship of his melancholy to the needed perseverance that gets connected with resilience as main tool to act flexibly on the unexpectedly encountered aggressive situations against Augustinus by acquainting a different attitude of mind.

He was thankful of having found a friend [24] in the addressee of the letter, Franciscus a S. Agnete. A friend, his most necessary need of direct personal interchange is somebody he on one hand probably requires and desires directly in the environment he is living in, on the other hand he gives the impression of strength by saying that he would feel consoled if there was at least one person available who was staying one or two days of travel distance and whom he could meet even just once a year. It is what he calls the 'alivio' [25], the necessary relief he could live with. Probably it would not have been a satisfactory solution - one just needs to think of his struggle of feeling attached to the mission and the missionary work itself, but discovering of 'hallo que me sera imposible perseverar en ella de la manera que aora quedo' [26]. It means, he needs a change under all circumstances, at least when respecting his own feelings. Especially when one considers the date this statement was done. It was in a letter to the provincial, dated November 27, 1678. Compared to the former statement of melancholy - it was probably at least decreased by the person of Franciscus of S. Agnete himself whom Augustinus thanked for, or was even grateful for having offered 'amistad', friendship instead of what Francisus psychologically enforces as negative contrary possibility that would have been a more or less strong sublime hostility that can be made out by the subtile allusions, as defined by Augustinus when he reflects the inter-personal dealing by saying 'porque en mi opinion aquella amistad toca el punto de ser verdadera, que en adversidades se manifiesta.' [27] - more than one year had passed, as the letter to Franscisus mentioned before had been written on June 18,1677 . One can see how the pressure had become much stronger by the passing time, even though the spiritual context comparable to some sources attributed to St. Francis is explicitly given already at the first stage of feeling this kind of melancholy. Two referrals are evident. With the definition of reading the letter of Franciscus a S. Agnete [28] as remedy he seems to have dealt with mainly spiritual scriptures' contents of St. Francis in order to gain some support as well as psychological stability and firmness.

Augustinus feels more than unfamiliar with China in comparison to Manila concerning country and customs, as he states that 'la tierra y las costumbres de los que la havitan me son aversos [...] [29]. This means that he feels a kind of hostility from two sides, the human one, possibly because he

\footnotetext{
${ }^{24}$ Augustinus, IX, 2, (1936, p. 438).

${ }^{25}$ Ibid., XIII, 8 (1936, p. 479).

26 ibid.

${ }^{27}$ ibid., IX, 2, (1936, p. 438).

${ }^{28}$ Augustinus, 1, $a$ Charta consumpta est., p. 437

${ }^{29}$ ibid., 2, p. 438.
} 
had been sent into mission to this for Augustinus and his personality difficult territory, and by the behaviour of Franciscus of S. Agnete that supports the feeling on, or the real situation of having more or less openly intriguing opponents in the whole (political)-missionary environment.

The spiritual consolation seeked for is in my opinion a refined combination of facing the whole situation as it is, and weaving into the relevant passage spiritual and regulative thoughts defined by St. Francis. There is on the object China the, let me call it criticism of a country where missionary work is profitable even though the country itself is, as seen before somehow bad for the feelings provoked, what continuously needs to be reflected under the component of loneliness and being emotionally lost in unfamiliar environment. Augustinus defines more the lacking presence 'corporal' that says what it is, the missing of at least one co-friar to share life with. The main aspect nevertheless is that Augustinus underlines that the spiritual distance is not that huge or insufferable as the corporal one, that can be seen on the one hand as the organisational one that is opponent of geographic reasons and human corporate dependencies in lacking communication and presence. On the other hand the coroporal aspect of a cofriars' presence in its execution is topic in a letter to Bonaventura de Ibañez (Nov. 26, 1679) in which he states that he would prefer to be subordinate to any future co-friar who should furthermore obtain the function of prelate. If this was the case in Shandong province Augustinus would prefer to buy some church, whereas he himself would look for some housing in Tingchenfu or in Chiningcheu in order that the co-friar was not forced to live together with Augustinus, as he declares himself as 'pues soi tan perverso hombre' [30]. Altogether Augstinus believes his demon to be cause of a kind of (inner) war that needs to be fought and that would keep in distance any possible co-friar to live with as soon as having gained awareness of Augustinus' psyche [31].

One does not know exactly why he defines himself as 'perverse man' especially as he has already experienced consolation by the letters and friendship of Franciscus a S. Agnete as mentioned before. This means that he has already frankly exposed his melancholia within an ordres' environment without having encountered any negative consequence except of the still missing co-friar he had asked for already about two years before. Another reason might be that Augustinus already in 1677 had gained a picture of the Chinese that meant that they were against Europeans living jointly, as the Chinese were afraid of occupation or buy-out of land. In that case three persons had been thought of living together by probably following the concept created by St. Francis of having a family-setting by defining mother - son(s) and brother(s) in duties towards each other when living in hermitages [32].

It is something that hurts the soul, what should not happen in a Franciscan environment as the admonitions about true love deal with the psychological issue of love given to

\footnotetext{
${ }^{30}$ Augustinus XVII., 6, p. 507.

${ }^{31}$ ibid., 5, p. 506.

${ }^{32}$ RegEins, 1-3, p. 206; 8-10, p. 207.
}

those co-friars who are far in distance and accordingly might be far in word if not creating closeness in word with love, and friendship as one attitude is given. It is a mode of caring for the other and requires in its basis of all people involved telling nothing treacherously about a person what could not be said directly. [33].

The main situation is sketched, and one can say that the relevant problems encountered from the very beginning, starting from the rejected licence and similar occurrences in the following years on others, additionally new problems in administrative aspects came up, whereas with the time of becoming more and more acquainted with the Chinese and their culture as well as being more and more involved into direct personal issues with co-friars Augustinus made it to become commissary from 1685 to 1690 . Nevertheless he had already asked for leaving this post on his own wish on April 4, 1689 [34], as the whole discrepancies between the situation of the mission in China and the European authorities who needed to give explanations in legalistic terms of interacting in Chinese territories treating among other things the question of those (French) missionaries who have come via Siam due to the war with the French without providing the correct papers for doing mission in China.

\section{Summary}

It can be seen that the topic of corporate intercourse is a very old one that in this special case of the Franciscan order can be traced back to the very beginning of the foundation in the 13th century. He had to reflect on what the success, maybe the glories of the examples given in the bible had been and what the then recent situation weakened the Church in its Christian spirits. This meant that he needed to organise the psychological structure of the whole corporation by knowing at the same time that it was necessary to adapt flexibly to any situation encountered as he was dealing in great geographic distances where it needed to be ensured that a main corporate human environment with specific requests towards the individual was regulated with the aim of providing an atmosphere of trust by human competence acquired through spiritual activity on oneself and in the dealings with the cofriars. It should not be the own inner corporate structure to cause bad atmosphere and feelings. Francis considered the fact that dealing in foreign cultures of different religious background needed a special requirement of inner peace used synonymously for the patience he was so aware of for giving joy to the individual being as all the other offenses and set backs from the outside towards and the inside of the person against oneself in finding ones way were harms one could not avoid, but needed to overcome consciously by active practice.

Nothing different is done nowadays when a company decides to act globally and wants to open the Chinese market for the own product(s). Predecessors' and

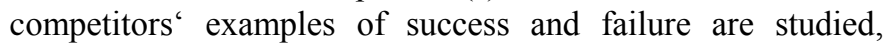
employees and workers suitable for international activity

\footnotetext{
${ }^{33}$ Erm, XXV.

${ }^{34}$ Augustinus XLIX, 10, p. 718.
} 
selected, psychological issues thought about and discussed, cultural trainings held, guides of conduct developed that consider for example dealing via media instead of physically working-closeness etc.

The topic itself is in its psychological structure of great importance, even though it might be rarely the case nowadays to not have any co-national or family member or person one is in relationship with that close, that ideas and problems cannot be shared immediately. One needs to dispose of psychological strategies to deal with ones own psyche when problems arise and any way of problem-solving, no matter whether activeacting or in the manner of "wu-wei takes place, where doing is a continuous state without enforcing the change itself, but being ready for waiting for the right time of change out of the consciousness that environments develop and change steadily and permanently without any ability and necessity to control and deal with everything on hand.

\section{References}

[1] St. Francis of Assisi. Regula non bullata [NbReg]. In: Hardick, Lothar \& Grau, Engelbert (eds.). "Die Schriften des heiligen Franziskus von Assisi”. Kevelaer: Butzon \& Bercker, 2001, p. 177-204.

[2] Stürner, Wolfgang: Friedrich II. Die Königsherrschaft in Sizilien und Deutschland 1194-1220, Darmstadt: Wissenschaftliche Buchgesellschaft, 1992.

[3] Thomas von Celano. Erste Lebensbeschreibung [I Cel], p. 73-215. Zweite Lebensbeschreibung [II Cel], p. 217-416. Leben und Wunder des heiligen Franziskus von Assisi. (ed.: Engelbert Grau), 5th ed., Werl /
Westf.: Dietrich-Coelde-Verlag, 1994.

[4] Bonaventura da Bagnoregio: Franziskus, Engel des sechsten Siegels. Das Große Franziskusleben [LM]. Sein Leben nach den Schriften des heiligen Bonaventura. (ed.: Sophronius Clasen). Werl / Westf.: DietrichCoelde-Verlag, 1962, p. 249-385.

[5] St. Francis of Assisi. Die wahre und vollkommene Freude [VollFreud]. In: Hardick, Lothar \& Grau, Engelbert (eds.). "Die Schriften des heiligen Franziskus von Assisi”. Kevelaer: Butzon \& Bercker, 2001, p. 225-227.

[6] St. Francis of Assisi. Brief an die Gläubigen II [BrGl II]. In: Hardick, Lothar \& Grau, Engelbert (eds.). "Die Schriften des heiligen Franziskus von Assisi”. Kevelaer: Butzon \& Bercker, 2001, p. 59-67.

[7] St. Francis of Assisi. Brief an die Kustoden II [BrKust II]. In: Hardick, Lothar \& Grau, Engelbert (eds.). "Die Schriften des heiligen Franziskus von Assisi”. Kevelaer: Butzon \& Bercker, 2001, p. 76-77.

[8] St. Francis of Assisi. Erklärung zum Vaterunser [ErklVat]. In: Hardick, Lothar \& Grau, Engelbert (eds.). "Die Schriften des heiligen Franziskus von Assisi”. Kevelaer: Butzon \& Bercker, 2001, p. 95-97.

[9] St. Francis of Assisi. Mahnlied für die Schwestern der heiligen Klara. [MahnKlara]. In: Hardick, Lothar \& Grau, Engelbert (eds.). "Die Schriften des heiligen Franziskus von Assisi". Kevelaer: Butzon \& Bercker, 2001, p. 135-138.

[10] Die Bibel. Stuttgart: Deutsche Bibelgesellschaft, 1990.

[11] Augustinus a S. Paschali: Epistolae et Relationes. In: Sinica Franciscana III (ed.: P. Anastasius van den Wyngaert), Firenze: Quaracchi, 1936, p. 330-804.

[12] St. Francis of Assisi. Regel für Einsiedeleien [RegEins]. In: Hardick, Lothar \& Grau, Engelbert (eds.). "Die Schriften des heiligen Franziskus von Assisi”. Kevelaer: Butzon \& Bercker, 2001, p. 205-207.

[13] St. Francis of Assisi. Ermahnungen [Erm]. In: Hardick, Lothar \& Grau, Engelbert (eds.). "Die Schriften des heiligen Franziskus von Assisi". Kevelaer: Butzon \& Bercker, 2001, p. 98-110. 